\section{US energy policy folly}

SIR - During the 1950s and 1960s, published studies forecast that a permanent decline in US oil production would start around 1970 (refs 1,2). Industry and government regarded these warnings as crying wolf; the accepted view was that the United States had all the oil it would need for the foreseeable future $\mathrm{s}^{3,4}$.

When the predicted decline in US oil production arrived on schedule, it was ignored; the United States simply imported more oil, doing nothing to curtail growth in oil consumption until shortages occurred. The shortages of 1973 and 1979, exacerbated by partial loss of foreign supply, were followed by accusations of collusion by the oil industry to create shortages.

Nevertheless, the decline in US oil production had begun in 1970 as predicted in 1956 (ref. 1), and it continues inexorably. The United States is now dependent on foreign sources for half of its oil supply and has demonstrated its willingness to wage war to ensure continued access to oil from the Persian Gulf.

The warnings of falling US oil production were based on geological constraints, well-drilling records and petroleum field discovery and production histories. Now, on the basis of analogous data, geologists warn that global oil production will peak and begin its permanent decline around the year 2020 (refs 5 and 6). This message is as unpopular today as was its analogue in the 1950s.

US citizens pay much less for gasoline than do people in other industrialized countries, consume more oil each year than those any other country and resist modest increase in fuel taxes, while US car-makers have successfully fought more stringent automotive fuel economy standards. If current US demand for oil persists, increasing dependence on Persian Gulf supply will cause higher oil prices; in time the United States may not be able to afford the oil it demands. Recent history suggests that this could lead to war in the Middle East over the last of the world's oil reserves.

A crisis is commonly a long-term problem not faced soon enough. The United States, by ignoring such problems until catastrophe is at hand, seems willing to believe anything but the truth. A rational long-term view is that permanently and significantly higher fuel prices through government surtax would encourage sustained fuel conservation as well as research on substitutes for conventional oil.

But US political leaders hoping for re-election will not advocate a long-term solution that requires immediate economic sacrifice by their constituents. All voters use crude oil derivatives, and higher oil prices are unpopular. A congress- man, although aware that higher fuel prices are in the long-term public interest, also knows that they will engender shortterm economic hardship without perceived benefit for several elections ahead, and thus lead to electoral disadvantage.

Consider what happened to President Jimmy Carter for acknowledging the severity of the energy problem. Compare this with President Ronald Reagan's popularity, resulting in part from his denial of the energy problem.

If an important but unpopular idea does not receive a fair hearing, public education is the solution. The US government will continue to ignore its energy problem until it escalates to crisis proportions unless a well-informed constituency demands action based on long-term considerations in spite of short-term economic hardship. So far, the American public demands more fuel than any other nation at prices lower than other nations pay. The course of major events during the next three decades could hinge on whether the US people learn that this demand cannot be satisfied much longer. Craig Bond Hatfield

Department of Geology,

University of Toledo,

Toledo, Ohio 43606, USA

1. Hubbert, M. K. Drilling and Production Practice $7-25$ (American Petroleum Institute Washington, DC 1956).

2. Hubbert, M. K. Energy Resource, a Report to the

Committee on Natural Resources Publ. 1000-D (Nationa Research Council, National Academy of Sciences. Washington, DC, 1962).

3. Domestic and World Resources of Fossil Fuels, Radioactive Minerals, and Geothermal Energy (US Geological Survey, assembled for National Academy of Sciences, Washington, DC 1961)

4. Zapp, A. D. Future Petroleum Production Capacity of the United States Bull. 1142-H (US Geological Survey, Washington, DC, 1961).

5. Hatfield, C. B. \& Ruedisili, L. C. Houston Geol. Soc. Bull 32, 21-29 (1990)

6. Masters, C. D., Root, D. H. \& Attanasi, E. D. Science 253 146-152(1991).

\section{Adversarial system in science}

SIR - Scientists criticize adversarial systems in law, but, in my opinion, the system has an unrecognized part to play in science. The facts relating to almost any serious scientific problem may usually be interpreted in more than one way. There are also many ways in which to preselect the facts considered. This means that the same data may have several different, and frequently opposite, explanations.

Unfortunately, the ability of the human mind to find an alternative explanation of

Letters submitted for Correspondence should be typed, double-spaced, on one side of the paper only. facts once a plausible one has been proposed is extremely poor; I call that phenomenon the presumption of the first explanation.

The history of science demonstrates that it may take tens to thousands of years to understand that the same facts may be interpreted in alternative ways. For example, Ptolemy's Earth-centred cosmology had been about for 1,400 years before it was replaced by the Sun-centred system by Copernicus, based on the same facts.

The question for science is how can we shorten these periods of self-deception, when the community as a whole believes that the truth has been already found?

The adversarial system offers a way of solving the problem. It is time to understand that consensus in the scientific community is not a good sign, but rather a symptom of a crisis. The polarization of views is normal.

One of the lessons of history is that nobody can know what is the ultimately proved truth. Any theory is only a viewpoint from which we look at the world. From some viewpoints, more elements are perceptible, from others, fewer. But the greater the number of viewpoints, the richer picture of the real world we have. P. Feyerabend's "proliferation of theories" has to become the way forward for science.

Vladimir Kolladin

Apt 128 ,

162-G Tractorostroiteley Avenue,

Kharkov 310129, Ukraine

\section{Pauling's missed Nobel prize}

SIR - You say it is a mystery why Linus Pauling did not identify the structure of DNA before Watson and Crick (Nature 370, 584; 1994). Pauling did not think it was a mystery.

He was a passenger on a flight of mine from Miami to San Francisco in the early 1980s when I was a United Air Lines captain. Having once been his neighbour, and having talked to him before (he advised me once while at the check-out counter of the Portola Valley Market to forgo buying a particular brand of toilet paper for another, "it's cheaper and better!"), I went back to talk to him after we settled down in cruise.

I mentioned I had just read The Double Helix and, knowing from the book he had been on the same track, I volunteered: "You came very close to being the first recipient of three Nobels". He answered: "Yes, I was weeks away, and if they had not got hold of Franklin's X-rays I would have beaten them to it."

George Fulford

218 Reed Circle,

Mill Valley, California 94941, USA 